\title{
Deoxyribonucleic Acid Reassociation in the Classification of the Genus Rhodococcus Zopf 1891 (Approved Lists, 1980)
}

\author{
M. MORDARSKI, ${ }^{1}$ M. GOODFELLOW, ${ }^{2}$ I. KASZEN, ${ }^{1}$ A. TKACZ, ${ }^{1}$ G. PULVERER ${ }^{3}$ AND K. P. \\ SCHAAL $^{3}$
}

Department of Biosynthesis, Institute of Immunology and Experimental Therapy, Wroclaw, Poland ${ }^{1}$; Department of Microbiology, The Medical School, The University, Newcastle upon Tyne NE1 7RU, United Kingdom ${ }^{2}$; and Institute of Hygiene, University of Cologne, Cologne, Federal Republic of Germany ${ }^{3}$

We determined the degree of binding between deoxyribonucleic acid (DNA) preparations from representative rhodococci and thymine-labeled DNAs (derived from labeled uracil) from the following six reference strains: Rhodococcus coprophilus (Approved Lists, 1980) strain N744, R. corallinus (Bergey et al. 1923) Goodfellow and Alderson 1979 (Approved Lists, 1980) strain N657, R. equi (Approved Lists, 1980) strain C7, R. rhodochrous (Approved Lists, 1980) strain N54, $R$. ruber (Approved Lists, 1980) strain N361, and $R$. rubropertinctus (Hefferan 1904) Goodfellow and Alderson 1979 (Approved Lists, 1980) strain N4. Although the congruence between the DNA reassociation and earlier numerical phenetic data was good, there was evidence that some strains had been misclassified in the numerical phenetic study. In particular, strains labeled $R$. corallinus (including the type strain of $R$. corallinus) and $R$. rubropertinctus belonged to a single DNA homology group. The former name is thus a later, subjective synonym of the latter. The guanine plus cytosine contents of the DNAs of the rhodococci fell within the range of 65 to $73 \mathrm{~mol} \%$.

The genus Rhodococcus Zopf 1891 (34) (Approved Lists, 1980 [29]) was reintroduced (9), was introduced the basis of numerical phenetic data, for some organisms previously classified as Corynebacterium (2), Gordona (32), Jensenia (1), Proactinomyces $(4,18)$, Nocardia $(2,20)$, and "Mycobacterium" rhodochrous (2, 15, 16, 28 ) or assigned to the "rhodochrous" complex $(2,10,11)$. In addition to the type species, Rhodococcus rhodochrous, nine species were recognized, including $R$. coprophilus $(9,26)$, which contains strains found in herbivore dung (27).

Because numerical relationships between strains can be distorted by factors such as sampling and test errors, differences in growth rate, etc., it is important to evaluate numerical classifications by using other powerful taxonomic methods (30). Thus, after numerical analysis, representative strains can be selected from defined clusters and examined by using more analytical methods which cannot readily be applied to many strains. The agreement found among data derived from the application of several independent taxonomic methods is a measure of the reliance that can be placed in a classification $(14,30)$.

Good agreement has been found between deoxyribonucleic acid (DNA)-DNA pairing and numerical phenetic data in a number of genera, including some of those in the order Actinomycetales (Approved Lists, 1980 [29]) (30, 31). In most instances, strains classified in well-defined taxospecies have approximately $70 \%$ DNA in common, with lower homology values reflecting significant genetic divergence (7). However, DNA homology values should not be regarded as absolute values, for they are not free from experimental error and are especially sensitive to the temperature at which reassociation is conducted $(3,13)$.

In earlier DNA-DNA pairing assays, representatives of several species of Rhodococcus formed genetically homogeneous taxa $(23,24)$. In this investigation these preliminary experiments were extended to include additional representative rhodococci and reference systems in order to help establish the infrageneric classification of the genus.

\section{MATERIALS AND METHODS}

Bacterial strains and growth conditions. The test organisms and their sources are given in Table 1. Detailed descriptions exist for most of the strains (8, 9). The procedures for cultivating strains and preparing biomass and the method used for obtaining purified DNA have all been described in detail elsewhere (23).

Preparations of radioactive DNA for homology studies. Uracil-labeled cells were grown and centrifuged, and the thymine-labeled DNA derived from the uracil was extracted and purified as described previously (23). Labeled reference DNA was prepared from the following six strains: $R$. coprophilus N744 
TABLE 1. Designations, sources, and DNA base compositions of test strains

\begin{tabular}{|c|c|c|}
\hline Strain and source ${ }^{a}$ & Laboratory no. & $\begin{array}{l}\text { G+C content of } \\
\text { DNA (mol\%) }\end{array}$ \\
\hline \multicolumn{3}{|l|}{ R. coprophilus Rowbotham and Cross 1979 (Approved Lists 1980 [29]) } \\
\hline $\begin{array}{l}\text { T.J. Rowbotham, Bradford University, England, CUB 628; L.G. Wil- } \\
\text { loughby, lake mud, Blelham Tarn, Cumbria }\end{array}$ & N650 & 71.1 \\
\hline T.J. Rowbotham, CUB 118; T. Cross, lake mud, Blelham Tarn & N651 & 67.4 \\
\hline T.J. Rowbotham, N38 & N652 & 72.0 \\
\hline T.J. Rowbotham, N19 & N653 & 69.8 \\
\hline NCIB 11211; T.J. Rowbotham, CUB 687 & N744 ${ }^{b}$ & 69.3 \\
\hline \multicolumn{3}{|l|}{$\begin{array}{l}R . \text { corallinus (Bergey et al. 1923) Goodfellow and Alderson } 1979 \text { (Ap- } \\
\text { proved Lists, } 1980[29] \text { ) }\end{array}$} \\
\hline $\begin{array}{l}\text { R. Bönicke, Institut für Experimentelle Biologie und Medizin, Borstel, } \\
\text { Federal Republic of Germany, SN5302 }\end{array}$ & N451 & 67.1 \\
\hline NCTC $10668 ; M$. Tsukamura, 3605 & $\mathrm{~N} 657^{h}$ & 69.0 \\
\hline \multicolumn{3}{|l|}{$\begin{array}{l}\text { R. egui (Magnusson 1923) Goodfellow and Alderson } 1979 \text { (Approved } \\
\text { Lists, } 1980[29] \text { ) }\end{array}$} \\
\hline NC'TC 1621 & $\mathrm{C}^{b}$ & 70.4 \\
\hline ATCC 25694 & R39 & 70.8 \\
\hline ATCC 25728 ; R.E. Gordon, 1256 & R70 & 69.2 \\
\hline ATCC $25729 ;$ R.E. Gordon, 1621 & R71 & 70.3 \\
\hline \multicolumn{3}{|l|}{$\begin{array}{l}R \text {. rhodochrous (Zopf 1891) Tsukamura } 1974 \text { (Approved Lists, } 1980 \\
{[29] \text { ) }}\end{array}$} \\
\hline NCIB 9701 & N5 & 69.8 \\
\hline R.E. Gordon, Rutgers University, New Brunswick, N.J., W21 & N31 & 69.1 \\
\hline ATCC 13808; R.E. Gordon, 372 & $\mathbf{N} 54^{b}$ & 69.5 \\
\hline R.E. Gordon, W3408 & N61 & 70.1 \\
\hline $\begin{array}{l}\text { S.T. Williams, Botany Department, Liverpool University, England, } \\
\text { E41 }\end{array}$ & N84 & 72.7 \\
\hline R.E. Gordon, W3639 & $\mathrm{N} 110$ & 68.6 \\
\hline ATCC 999 & R4 & 69.8 \\
\hline ATCC 4001 & R5 & 68.6 \\
\hline ATCC 14341 & R10 & 67.5 \\
\hline ATCC 14349 & R14 & 69.1 \\
\hline ATCC $25722 ;$ R.E. Gordon, 1022 & $\mathrm{R} 64$ & 68.2 \\
\hline ATCC 25725 ; R.E. Gordon, $1082 \mathrm{~S}$ & R67 & 67.0 \\
\hline ATCC $25731 ;$ R.E. Gordon, W3407 & R73 & 67.7 \\
\hline \multicolumn{3}{|l|}{$\begin{array}{l}\text { R. ruber (Kruse 1896) Goodfellow and Alderson } 1979 \text { (Approved Lists, } \\
1980[29] \text { ) }\end{array}$} \\
\hline ATCC 15998 & N324 & 71.7 \\
\hline $\begin{array}{l}\text { M. Tsukamura, Chuba Chest Hospital, Obu, Aichi-ken, 474, Japan, } \\
\text { M-1 }\end{array}$ & N361 & 72.3 \\
\hline M. Tsukamura, M-192; R.E. Gordon, R-680 & N363 & 72.6 \\
\hline A. Tacquet, Pasteur Institute, Lille, France, 906 & $\mathbf{N} 420$ & 71.4 \\
\hline R. Bönicke, SN5108 & N447 & 71.5 \\
\hline R. Bönicke, SN5201 & N454 & 70.4 \\
\hline R. Bönicke, SN5102 & $\mathbf{R} 179$ & 72.2 \\
\hline R. Bönicke, SN5103 & $\mathrm{R} 180$ & 72.0 \\
\hline R. Bönicke, SN5104 & $\mathrm{R} 181$ & 72.5 \\
\hline R. Bönicke, SN5105 & $\mathrm{R} 182$ & 71.5 \\
\hline R. Bönicke, SN5107 & R183 & 70.5 \\
\hline R. Bönicke, SN5108 & $\mathrm{R} 184$ & 72.4 \\
\hline R. Bönicke, SN5109 & $\mathrm{R} 185$ & 70.5 \\
\hline R. Bönicke, SN5110 & $\mathrm{R} 186$ & 71.5 \\
\hline R. Bönicke, SN5112 & R187 & 70.8 \\
\hline \multicolumn{3}{|l|}{$\begin{array}{l}R \text {. rubropertinctus (Hefferan 1904) Goodfellow and Alderson } 1979 \text { (Ap- } \\
\text { proved Lists, } 1980[29] \text { ) }\end{array}$} \\
\hline NCIB 9664 & $\mathrm{~N}_{4}^{b}$ & 67.7 \\
\hline V.B.D. Skerman, Queensland University, Australia, 134 & N113 & 69.1 \\
\hline M. Turner, Nottingham University, England, 39 & N146 & 65.1 \\
\hline ATCC 25689 & R35 & 68.2 \\
\hline
\end{tabular}

${ }^{a}$ A'TCC, American Type Culture Collection, Rockville, Md.; CUB, Collection of the University of Bradford, Bradford, England; NCIB, National Collection of Industrial Bacteria, Aberdeen, Scotland.

"Type strain (29). 
(=NCIB 11211), $R$. corallinus N657 (=NCTC 10668), R. equi C7 (=NCTC 1621), $R$. rhodochrous N54 (=ATCC 13808), R. ruber N361 (=M. Tsukamura M1 ), and $R$. rubropertinctus N4 (=NCIB 9664). The specific activities of the reference DNA preparations are shown in Tables 2 and 3.

Analysis of DNA base compositions. The guanine plus cytosine $(\mathrm{G}+\mathrm{C})$ contents of the DNAs were determined by the thermal denaturation method of Marmur and Doty (19); the denaturations were performed in $0.1 \times \mathrm{SSC}(1 \times \mathrm{SSC}$ is $0.15 \mathrm{M} \mathrm{NaCl}$ plus 0.015 $M$ trisodium citrate).

Fixation of denatured, high-molecular-weight DNA on membrane filters and DNA-DNA pairing. Homology values were determined by establishing the extent to which immobilized, single-stranded DNA bound labeled reference DNA in solution. The pairing was performed for $18 \mathrm{~h}$ at $64^{\circ} \mathrm{C}$ on nitrocellulose membranes (Sartorius SM-1140) in $2 \times$ SSC containing $30 \%$ (vol/vol) dimethyl sulfoxide. The thermal denaturation $\left(T_{m}\right)$ values of the DNAs used in these experiments varied depending on the $\mathrm{G}+\mathrm{C}$ content; the mean optimal temperature was $86^{\circ} \mathrm{C}$. Further details of the methods used have been described elsewhere (24).

Thermal stability of DNA-DNA duplexes. The thermal stability of duplexes formed between filterbound and reference DNAs was determined from $T_{m(e)}$ values. $\left(T_{m(e)}\right.$ was the temperature at which one-half of the reassociated reference DNA became dissociated and eluted from the test DNA bound to the filter.) The $T_{m(e)}$ was found by subtracting the $T_{m(e)}$ of the hybrid of a heterologous system from the $T_{m(e)}$ of a homologous duplex (25). Thus, once pairing was completed, the filters were dried and then eluted with $0.1 \times$ SSC at temperature increments of $5^{\circ} \mathrm{C}$ over the range 70 to $100^{\circ} \mathrm{C}$. The radioactive samples were assayed in the scintillation fluid of Bray (6). The thermal stability of duplexes was determined only where reassociation values of more than $30 \%$ were obtained.

\section{RESULTS AND DISCUSSION}

The case for the reintroduction of the genus Rhodococcus (9) has been supported by the results of further numerical phenetic, chemical, and genetic studies $(10,11,21,27,33)$. In preliminary studies on representatives of some of the recognized Rhodococcus species, good congruence was found between DNA-DNA homology and numerical phenetic data $(23,24)$. Thus, although there are difficulties in relating homology and similarity values, $R$. bronchialis (Approved Lists, 1980 [29]), $R$. erythropolis (Gray and Thornton 1928) Goodfellow and Alderson 1979 (Approved Lists, 1980 [29]), R. rhodoch ; rous, $R$. ruber, and $R$. terrae (Approved Lists, 1980 [29]) appeared to be good species on both numerical phenetic and genetic grounds (12). The results of the present study confirm and extend these earlier observations (Tables 1, 3, and 4). The DNA reassociation rates of the reference strains are shown in Table 2 . It is evident that $R$. corallinus $\mathrm{N} 657$ and $R$. rubropertinctus $\mathrm{N} 4$ are closely related and that the remaining reference systems are quite distinct.

The DNA-DNA pairing data confirmed the homogeneity of the type species, $R$. rhodochrous, and showed that three strains were misplaced in this taxon (Table 3). $R$. rhodochrous R67 shares little genetic similarity with any of the reference systems and should be included in future comparative studies, whereas $R$. rhodochrous $\mathrm{N} 84$ and N110 should be reclassified as $R$. ruber. In contrast, $R$. ruber $\mathrm{N} 454$, together with $R$. equi R70, should be transferred to $R$. rhodochrous. Since $R$. rhodochrous and $R$. ruber share a high intercluster similarity (9), factors such as test or sampling error might account for the observed misclassification of strains between these species. All of the $R$. rhodochrous strains have a narrow DNA base composition range of 67.5 to $70.4 \mathrm{~mol} \% \mathrm{G}+\mathrm{C}$ (Table 1). It is well known that base ratio estimations are influenced by the methods and formulas used (5); the lower

TABLE 2. DNA-DNA reassociation rates of the reference strains ${ }^{a}$

\begin{tabular}{|c|c|c|c|c|c|c|c|c|c|c|c|c|c|}
\hline \multirow{3}{*}{$\begin{array}{l}\text { Labora- } \\
\text { tory no. of } \\
\text { strain }\end{array}$} & \multirow{3}{*}{ DNA } & \multicolumn{12}{|c|}{$\%$ Reassociation with strain: } \\
\hline & & \multicolumn{2}{|c|}{$\mathrm{C7}$} & \multicolumn{2}{|c|}{ N4 } & \multicolumn{2}{|c|}{ N54 } & \multicolumn{2}{|c|}{ N361 } & \multicolumn{2}{|c|}{ N657 } & \multicolumn{2}{|c|}{ N744 } \\
\hline & & $\begin{array}{l}\text { Unla- } \\
\text { beled } \\
\text { DNA }\end{array}$ & $\begin{array}{l}\text { La- } \\
\text { beled } \\
\text { DNA }\end{array}$ & $\begin{array}{l}\text { Unla- } \\
\text { beled } \\
\text { DNA }\end{array}$ & $\begin{array}{c}\text { La- } \\
\text { beled } \\
\text { DNA }\end{array}$ & $\begin{array}{l}\text { Unla- } \\
\text { beled } \\
\text { DNA }\end{array}$ & $\begin{array}{c}\text { La- } \\
\text { beled } \\
\text { DNA }\end{array}$ & $\begin{array}{l}\text { Unla- } \\
\text { beled } \\
\text { DNA }\end{array}$ & $\begin{array}{l}\text { La- } \\
\text { beled } \\
\text { DNA }\end{array}$ & $\begin{array}{l}\text { Unla- } \\
\text { beled } \\
\text { DNA }\end{array}$ & $\begin{array}{l}\text { La- } \\
\text { beled } \\
\text { DNA }\end{array}$ & $\begin{array}{l}\text { Unla- } \\
\text { beled } \\
\text { DNA }\end{array}$ & $\begin{array}{c}\text { La- } \\
\text { beled } \\
\text { DNA }\end{array}$ \\
\hline \multirow[t]{2}{*}{ C7 } & Labeled & 100 & & 8 & & 16 & & 13 & & 8 & & 13 & \\
\hline & Unlabeled & & & & 8 & & 11 & & 13 & & 6 & & 13 \\
\hline \multirow[t]{2}{*}{ N4 } & Labeled & & & 100 & & 10 & & 9 & & 58 & & 8 & \\
\hline & Unlabeled & & & & & & 9 & & 10 & & 74 & & 7 \\
\hline \multirow[t]{2}{*}{ N54 } & Labeled & & & & & 100 & & 17 & & 9 & & 15 & \\
\hline & Unlabeled & & & & & & & & 23 & & 8 & & 20 \\
\hline \multirow[t]{2}{*}{ N361 } & Labeled & & & & & & & 100 & & 10 & & 13 & \\
\hline & Unlabeled & & & & & & & & & & 6 & & 14 \\
\hline \multirow[t]{2}{*}{ N657 } & Labeled & & & & & & & & & 100 & & 7 & \\
\hline & Unlabeled & & & & & & & & & & & & 7 \\
\hline N744 & Labeled & & & & & & & & & & & 100 & \\
\hline
\end{tabular}

a The reassociation conditions are described in Table 3 , footnote $a$. 
TABLE 3. Reassociation of DNA samples from Rhodococcus strains with DNAs from reference strains $R$. rhodochrous $N 54, R$. ruber N361, and $R$. coprophilus $N 744^{a}$

\begin{tabular}{|c|c|c|c|c|c|c|c|}
\hline \multicolumn{2}{|c|}{ DNA source } & \multicolumn{6}{|c|}{ Labeled DNA source } \\
\hline \multirow[b]{2}{*}{ Species } & \multirow[b]{2}{*}{ Strain } & \multicolumn{2}{|c|}{ R. coprophilus $\mathrm{N}^{744^{b}}$} & \multicolumn{2}{|c|}{ R. rhodochrous ${\mathrm{N} 54^{b}}^{b}$} & \multicolumn{2}{|c|}{ R. ruber N361 } \\
\hline & & $\begin{array}{c}\text { Relative amt of } \\
\text { DNA bound } \\
\text { (\%) }\end{array}$ & $T_{m(e)}\left({ }^{\circ} \mathrm{C}\right)$ & $\begin{array}{l}\text { Relative amt of } \\
\text { DNA bound } \\
(\%)\end{array}$ & $T_{n a(e)}\left({ }^{\circ} \mathrm{C}\right)$ & $\begin{array}{l}\text { Relative amt of } \\
\text { DNA bound } \\
(\%)\end{array}$ & $T_{m(e)}\left({ }^{\circ} \mathrm{C}\right)$ \\
\hline \multirow[t]{5}{*}{ R. coprophilus } & $\mathrm{N} 744^{b}$ & 100 & & $15 \pm 0^{c}$ & & $13 \pm 1$ & \\
\hline & N651 & $68 \pm 3$ & 1 & $20 \pm 0.5$ & & $14 \pm 0.5$ & \\
\hline & N650 & $51 \pm 1$ & 1 & $20 \pm 0.5$ & & $99 \pm 2$ & 3 \\
\hline & N653 & $43 \pm 2$ & 0.5 & $20 \pm 1$ & & $17 \pm 0.5$ & \\
\hline & N652 & $8 \pm 1$ & & $11 \pm 0.5$ & & $13 \pm 1$ & \\
\hline \multirow[t]{13}{*}{ R. rhodochrous } & $\mathrm{N} 54^{b}$ & $20 \pm 1$ & & 100 & & $23 \pm 0.5$ & \\
\hline & N61 & $18 \pm 0.5$ & & $93 \pm 2$ & 1 & $26 \pm 1$ & \\
\hline & $\mathrm{N} 31$ & $21 \pm 1$ & & $92 \pm 3$ & 0 & $22 \pm 1$ & \\
\hline & $\mathrm{R} 10$ & $15 \pm 1$ & & $84 \pm 4$ & 0 & $19 \pm 1$ & \\
\hline & R14 & $17 \pm 0$ & & $79 \pm 0$ & 1 & $22 \pm 1$ & \\
\hline & R73 & $19 \pm 0$ & & $72 \pm 0$ & 1.5 & $23 \pm 1$ & \\
\hline & $\mathrm{R} 4$ & $16 \pm 1$ & & $62 \pm 2$ & 1.5 & $16 \pm 1$ & \\
\hline & $\mathrm{R} 64$ & $20 \pm 1$ & & $58 \pm 0$ & 4.5 & $25 \pm 1$ & \\
\hline & N5 & $11 \pm 0.5$ & & $50 \pm 0$ & 0 & $15 \pm 0.5$ & \\
\hline & R5 & $7 \pm 0$ & & $40 \pm 0$ & 3.5 & $10 \pm 0.5$ & \\
\hline & R67 & $7 \pm 0.5$ & & $26 \pm 0$ & & $7 \pm 0$ & \\
\hline & N84 & $14 \pm 0$ & & $23 \pm 0.5$ & & $96 \pm 4$ & 1 \\
\hline & N110 & $12 \pm 1$ & & $15 \pm 1$ & & $89 \pm 3$ & 1 \\
\hline \multirow{15}{*}{ R. ruber } & N361 & $14 \pm 1$ & & $17 \pm 0$ & & 100 & \\
\hline & N447 & $16 \pm 2$ & & $26 \pm 1$ & & $114 \pm 1$ & 3 \\
\hline & $\mathrm{R} 181$ & $15 \pm 1$ & & $23 \pm 1$ & & $104 \pm 3$ & 1 \\
\hline & $\mathrm{R} 184$ & $13 \pm 0$ & & $20 \pm 0.5$ & & $104 \pm 5$ & 0 \\
\hline & $\mathrm{R} 186$ & $15 \pm 1$ & & $24 \pm 0$ & & $104 \pm 3$ & 0 \\
\hline & N420 & $11 \pm 0$ & & $17 \pm 0$ & & $102 \pm 3$ & 0 \\
\hline & $\mathrm{R} 179$ & $14 \pm 0.5$ & & $22 \pm 0.5$ & & $100 \pm 1$ & 3 \\
\hline & N363 & $14 \pm 0$ & & $20 \pm 0$ & & $97 \pm 3$ & 1 \\
\hline & R180 & $13 \pm 0.5$ & & $18 \pm 0.5$ & & $97 \pm 0.5$ & 2 \\
\hline & $\mathrm{R} 182$ & $15 \pm 0.5$ & & $18 \pm 0.5$ & & $91 \pm 2$ & 1 \\
\hline & R187 & $13 \pm 0$ & & $19 \pm 0$ & & $89 \pm 1$ & 0.5 \\
\hline & $\mathrm{R} 183$ & $13 \pm 0$ & & $23 \pm 0.5$ & & $87 \pm 4$ & 0 \\
\hline & $\mathrm{N} 324$ & $9 \pm 0$ & & $16 \pm 1$ & & $79 \pm 5$ & 1.5 \\
\hline & R185 & $8 \pm 1$ & & $13 \pm 0$ & & $71 \pm 3$ & 0 \\
\hline & N454 & $21 \pm 0.5$ & & $65 \pm 1$ & 4.0 & $27 \pm 1$ & \\
\hline \multirow[t]{2}{*}{ R. corallinus } & $\mathrm{N} 657^{b}$ & $7 \pm 0.5$ & & $9 \pm 0.5$ & & $10 \pm 0$ & \\
\hline & N451 & $6 \pm 0$ & & $8 \pm 0$ & & $9 \pm 0.5$ & \\
\hline \multirow[t]{4}{*}{ R. equi } & $\mathrm{C} 7^{b}$ & $13 \pm 1$ & & $11 \pm 0$ & & $13 \pm 0.5$ & \\
\hline & R39 & $11 \pm 0.5$ & & $15 \pm 0$ & & $18 \pm 0.5$ & \\
\hline & $\mathrm{R} 71$ & $10 \pm 0$ & & $13 \pm 0.5$ & & $33 \pm 1$ & 0 \\
\hline & $\mathrm{R} 70$ & $19 \pm 0.5$ & & $74 \pm 0$ & 0.5 & $25 \pm 0.5$ & \\
\hline \multirow{4}{*}{$\begin{array}{l}\text { R. rubropertinc- } \\
\text { tus }\end{array}$} & $\mathbf{N} 4^{\prime \prime}$ & $7 \pm 0.5$ & & $9 \pm 0$ & & $10 \pm 0$ & \\
\hline & $\mathrm{R} 35$ & $7 \pm 0$ & & $8 \pm 1$ & & $9 \pm 0$ & \\
\hline & $\mathrm{N} 113$ & $6 \pm 0.5$ & & $8 \pm 0.5$ & & $7 \pm 0$ & \\
\hline & N146 & $7 \pm 0.5$ & & $8 \pm 0$ & & $9 \pm 0.5$ & \\
\hline
\end{tabular}

"The extent of binding between the DNA from a test strain and labeled DNA from a reference strain is expressed as a percentage relative to the extent of binding between labeled and unlabeled DNAs from the reference strain itself. $\Delta T_{m(e)}$, a measure of the thermal stability of the DNA-DNA duplexes, was obtained by subtracting the $T_{m(e)}$ (the midpoint of thermal elution) of the molecular hybrids of the heterologous system from the $T_{\text {miel }}$ of the homologous hybrids. The ratio of labeled DNA to unlabeled DNA was 1:15. The background imp per minute per membrane did not exceed 1 to $2 \%$ of the value in the homologous system.

${ }^{b}$ Type strain (29). The specific activities of DNA samples from the reference strains were as follows: $R$. coprophilus N744, $6,288 \mathrm{cpm} / \mu \mathrm{g}$; R.rhodochrous N54, 4,571 cpm/ $/ \mu \mathrm{g}$; and $R . r u b e r ~ N 361,2,473 \mathrm{cpm} / \mu \mathrm{g}$.

Mean \pm standard error. 
TABLE 4. Reassociation of DNA samples from Rhodococcus strains with DNAs from reference strains $R$. corallinus N657, R. equi $C 7$, and $R$. rubropertinctus $N 4^{a}$

\begin{tabular}{|c|c|c|c|c|c|c|c|}
\hline \multicolumn{2}{|c|}{ DNA source } & \multicolumn{6}{|c|}{ Labeled DNA source } \\
\hline \multirow[b]{2}{*}{ Species } & \multirow[b]{2}{*}{ Strain } & \multicolumn{2}{|c|}{ R. corallinus $\mathrm{N} 657^{b}$} & \multicolumn{2}{|c|}{ R. equi $\mathrm{C}^{b}$} & \multicolumn{2}{|c|}{ R. rubropertinctus $\mathrm{N}^{b}$} \\
\hline & & $\begin{array}{l}\text { Relative amt of } \\
\text { DNA bound } \\
\text { (\%) }\end{array}$ & $T_{m(e)}\left({ }^{\circ} \mathrm{C}\right)$ & $\begin{array}{l}\text { Relative amt of } \\
\text { DNA bound } \\
(\%)\end{array}$ & $T_{m(e)}\left({ }^{\circ} \mathrm{C}\right)$ & $\begin{array}{l}\text { Relative amt of } \\
\text { DNA bound } \\
\text { (\%) }\end{array}$ & $T_{m(e)}\left({ }^{\circ} \mathrm{C}\right)$ \\
\hline \multirow[t]{5}{*}{ R. coprophilus } & $\mathrm{N} 744^{b}$ & $7 \pm 0^{c}$ & & $13 \pm 0$ & & 8 & \\
\hline & $\mathrm{N} 651$ & $6 \pm 1$ & & $10 \pm 0.5$ & & 12 & \\
\hline & N650 & $6 \pm 0$ & & $16 \pm 1$ & & 12 & \\
\hline & N653 & $6 \pm 0$ & & $11 \pm 0.5$ & & 11 & \\
\hline & N652 & $6 \pm 0$ & & $78 \pm 2$ & 1 & 11 & \\
\hline \multirow[t]{2}{*}{$R$. corallinus } & $\mathrm{N} 657^{b}$ & 100 & & $8 \pm 0$ & & 58 & 1 \\
\hline & N451 & $71 \pm 3$ & 4 & $10 \pm 0$ & & 68 & 0 \\
\hline \multirow[t]{4}{*}{ R. equi } & $\mathrm{C} 7^{b}$ & $6 \pm 0$ & & 100 & & 8 & \\
\hline & R39 & $7 \pm 0$ & & $99 \pm 3$ & 0.5 & 10 & \\
\hline & R71 & $7 \pm 0.5$ & & $98 \pm 2$ & 0.5 & 10 & \\
\hline & R70 & $7 \pm 0$ & & $15^{\prime} \pm 1$ & & 10 & \\
\hline \multirow{4}{*}{$\begin{array}{l}\text { R. rubropertinc- } \\
\text { tus }\end{array}$} & $\mathbf{N} 4^{b}$ & $74 \pm 4$ & 3 & $8 \pm 0$ & & 100 & \\
\hline & R35 & $53 \pm 1$ & 1 & $10 \pm 0.5$ & & 43 & 2.5 \\
\hline & N113 & $52 \pm 4$ & 1 & $7 \pm 0$ & & 38 & 2 \\
\hline & N146 & $5 \pm 0$ & & $10 \pm 0.5$ & & 8 & \\
\hline \multirow[t]{13}{*}{ R. rhodochrous } & N54 & $8 \pm 0$ & & $16 \pm 0$ & & 10 & \\
\hline & N61 & $7 \pm 0$ & & $15 \pm 1$ & & 11 & \\
\hline & N31 & $8 \pm 0$ & & $16 \pm 0.5$ & & 9 & \\
\hline & R10 & $6 \pm 0.5$ & & $14 \pm 0.5$ & & 9 & \\
\hline & $\mathrm{R} 14$ & $8 \pm 0$ & & $17 \pm 0$ & & 11 & \\
\hline & R73 & $7 \pm 0$ & & $15 \pm 0.5$ & & 13 & \\
\hline & $\mathrm{R} 4$ & $6 \pm 0$ & & $14 \pm 0.5$ & & 8 & \\
\hline & R64 & $9 \pm 0.5$ & & $18 \pm 1$ & & 12 & \\
\hline & N5 & $4 \pm 0$ & & $10 \pm 0$ & & 7 & \\
\hline & R5 & $3 \pm 0$ & & $7 \pm 0$ & & 5 & \\
\hline & R67 & $4 \pm 0$ & & $7 \pm 0.5$ & & 6 & \\
\hline & $\mathrm{R} 84$ & $8 \pm 0.5$ & & $20 \pm 0.5$ & & 12 & \\
\hline & N110 & $6 \pm 0$ & & $15 \pm 0.5$ & & 8 & \\
\hline \multirow[t]{15}{*}{ R. ruber } & N361 & $6 \pm 1$ & & $15 \pm 1$ & & 9 & \\
\hline & N447 & $9 \pm 0.5$ & & $19 \pm 1$ & & 16 & \\
\hline & R181 & $7 \pm 0.5$ & & $20 \pm 0$ & & 13 & \\
\hline & $\mathrm{R} 184$ & $6 \pm 0$ & & $15 \pm 0.5$ & & 11 & \\
\hline & R186 & $9 \pm 0.5$ & & $17 \pm 0$ & & 13 & \\
\hline & N420 & $5 \pm 0$ & & $12 \pm 0.5$ & & 11 & \\
\hline & R179 & $8 \pm 0$ & & $20 \pm 0.5$ & & 13 & \\
\hline & N363 & $9 \pm 0$ & & $16 \pm 0$ & & 12 & \\
\hline & R180 & $6 \pm 0$ & & $15 \pm 0.5$ & & 10 & \\
\hline & R182 & $7 \pm 0$ & & $15 \pm 1$ & & 12 & \\
\hline & R187 & $6 \pm 0.5$ & & $12 \pm 1$ & & 8 & \\
\hline & R183 & $7 \pm 0.5$ & & $15 \pm 1$ & & 12 & \\
\hline & N324 & $4 \pm 0$ & & $12 \pm 1$ & & 7 & \\
\hline & R185 & $4 \pm 0$ & & $9 \pm 0$ & & 6 & \\
\hline & N454 & $8 \pm 0$ & & $16 \pm 0$ & & 14 & \\
\hline
\end{tabular}

\footnotetext{
${ }^{a}$ See Table 3, footnote $a$.
}

${ }^{b}$ Type strain (29). The specific activities of DNA samples from the reference strains were as follows: $R$. corallinus $\mathrm{N} 657,7,000 \mathrm{cpm} / \mu \mathrm{g} ; R$. equi $\mathrm{C} 7,1,551 \mathrm{cpm} / \mu \mathrm{g}$; and $R$. rubropertinctus $\mathrm{N} 4,7,596 \mathrm{cpm} / \mu \mathrm{g}$.

${ }^{c}$ Mean \pm standard error. 
values recorded in earlier studies on rhodococci were based upon a chemical method (17), whereas those in the present study were determined by using the thermal denaturation method (19).

The recovery of $R$. ruber as a genetically homogeneous species is in good agreement with earlier nucleotide homology data (24) and with the results from chemical and fermentation studies (22). $R$. coprophilus N650 is almost identical genetically to $R$. ruber $\mathrm{N} 361$, but it also shares a lot of DNA in common with the $R$. coprophilus reference system. The $R$. ruber strains have a narrow base composition range (68.6 to $72.7 \mathrm{~mol} \% \mathrm{G}+\mathrm{C})$.

The DNA homology data support the status of $R$. coprophilus and $R$. equi as distinct species $(9,26)$ inasmuch as the type strains of each of these taxa have little DNA in common with one another or with the other reference systems studied (Tables 3 and 4). It is evident that $R$. coprophilus N652, which was not included in the numerical phenetic study of Rowbotham and Cross (26), should be transferred to $R$. equi. The $R$. coprophilus and $R$. equi strains form homogeneous groups on the basis of base composition, falling within the ranges of 67.4 to 69.8 and 70.3 to $72.0 \mathrm{~mol} \% \mathrm{G}+\mathrm{C}$, respectively.

In the numerical classification of Goodfellow and Alderson (9), subcluster 1G was labeled $R$. rubropertinctus because the name Nocardia rubropertincta was considered to have priority over other validly published names carried by type strains recovered in the subcluster. Most of the strains in subcluster 1G shared very high similarity values, but a few less closely related organisms found at or toward the periphery of the subcluster also showed a high affinity with the $R$. corallinus strains of subcluster $1 \mathrm{C}(9)$. Organisms found toward the periphery of the $R$. rubropertinctus subcluster included the type strain of $R$. rubropertinctus, strain $\mathrm{N} 4$, and strain R35. Subsequently, the analysis of menaquinone and mycolic acid composition provided further evidence of the heterogeneity of $R$. rubropertinctus (21).

It is evident from the DNA-DNA pairing data (Table 4) that $R$. corallinus N451 and N657 (the type strain of $R$. corallinus) should be classified in the same species as $R$. rubropertinctus N4, $\mathrm{R} 35$, and N113. Since $R$. rubropertinctus (Hefferan 1904) Goodfellow and Alderson has priority over $R$. corallinus (9), the latter becomes a later subjective synonym of $R$. rubropertinctus. Strains classified in this revised taxon have a DNA base composition within the range of 67.1 to $69.1 \mathrm{~mol} \% \mathrm{G}+\mathrm{C}$.

The good agreement found between the DNA homology and numerical phenetic data is en- couraging, but the results of the present study emphasize the importance of evaluating numerical classifications by using other powerful taxonomic methods. Although taxometric techniques provide a relatively quick and accurate way of determining zones of variation among poorly classified strains, it is not always easy to lay down sharp boundaries between defined clusters. It is clear from the present study, however, that the numerical phenetic and DNA reassociation methods are complementary and together provide a powerful way of clarifying the infrageneric relationships of ill-defined taxa.

The numerical phenetic and genetic data indicate that $R$. bronchialis, $R$. coprophilus, $R$. equi, $R$. erythropolis, $R$. rhodochrous, $R$. ruber, and $R$. terrae are good species. The DNA homology results show that the name $R$. corallinus should be reduced to the status of a junior synonym of $R$. rubropertinctus, with strain N4 (=NCIB 9664) as the type strain of the redefined species. Our studies are being extended to determine whether $R$. rhodnii (Approved Lists, 1980 [29]) and the rhodococci remaining in subcluster IG form distinct homology groups.

\section{REPRINT REQUESTS}

Address reprint requests to: Dr. M. Goodfellow, Department of Microbiology, The Medical School, The University, Newcastle upon Tyne NE1 7RU, United Kingdom.

\section{LITERATURE CITED}

1. Bisset, K. A., and F. W. Moore. 1950. Jensenia, a new genus of the Actinomycetales. J. Gen. Microbiol. 4:280.

2. Bousfield, I. J., and M. Goodfellow. 1976. The "rhodochrous" complex and its relationships with allied taxa, p. 39-65. In M. Goodfellow, G. H. Brownell, and J. A. Serrano (ed.), The biology of the nocardiae. Academic Press, Inc., London.

3. Bradley, S. G. 1975. Significance of nucleic acid hybridization to systematics of actinomycetes. Adv. Appl. Microbiol. 19:59-70.

4. Bradley, S. G., and J. S. Bond. 1974. Taxonomic criteria for mycobacteria and nocardiae. Adv. Appl. Microbiol. 18:131-190.

5. Bradley, S. G., and M. Mordarski. 1976. Association of polydeoxyribonucleotides of deoxyribonucleic acids from nocardioform bacteria, p. 310-366. In M. Goodfellow, G. H. Brownell, and J. A. Serrano (ed.), The biology of the nocardiae. Academic Press, Inc., London.

6. Bray, G. A. 1960 . A simple efficient liquid scintillator for counting aqueous solutions in a liquid scintillation counter. Anal. Biochem. 1:279-285.

7. Brenner, D. J. 1973. Deoxyribonucleic acid reassociation in the taxonomy of enteric bacteria. Int. J. Syst. Bacteriol. 23:298-307.

8. Goodfellow, M. 1971. Numerical taxonomy of some nocardioform bacteria. J. Gen. Microbiol. 69:33-80.

9. Goodfellow, M., and G. Alderson. 1977. The actinomycete-genus Rhodococcus: a home for the "rhodochrous" complex. J. Gen. Microbiol. 100:99-122.

10. Goodfellow, M., and D. E. Minnikin. 1977. Nocardioform bacteria. Annu. Rev. Microbiol. 31:159-180.

11. Goodfellow, M., and D. E. Minnikin. 1978. Numerical and chemical methods in the classification of Nocardia 
and related taxa. Zentralbl. Bakteriol. Parasitenkd. Infektionskr. Hyg. Abt. 1 Suppl. 6:43-51.

12. Goodfellow, M., M. Mordarski, K. Szyba, and G. Pulverer. 1978. Relationships among rhodococci based upon deoxyribonucleic acid reassociation. Zentralbl Bakteriol. Parasitenkd. Infektionskr. Hyg. Abt. 1 Suppl. 7:231-234.

13. Goodfellow, M., M. Mordarski, A. Tkacz, K. Szyba, and G. Pulverer. 1979. Polynucleotide sequence divergence among some coagulase-negative staphylococci. Zentralbl. Bakteriol. Parasitenkd. Infektionskr. Hyg. Abt. 1 Orig. Reihe A 246:10-22.

14. Goodfellow, M., P. A. B. Orlean, M. D. Collins, L. Alshamaony, and D. E. Minnikin. 1978. Chemical and numerical taxonomy of strains received as Gordona aurantiaca. J. Gen. Microbiol. 109:57-68.

15. Gordon, R. E. 1966. Some strains in search of a genusCorynebacterium, Mycobacterium, Nocardia or what? J. Gen. Microbiol. 43:329-343.

16. Gordon, R. E., and J. M. Mihm. 1959. A comparison of four species of mycobacteria. J. Gen. Microbiol. 21:736748.

17. Huang, P. C., and E. Rosenberg. 1966. Determination of DNA base composition via depurination. Anal. Biochem. 16:107-113.

18. Jensen, H. L. 1931. Contributions to our knowledge of the Actinomycetales. II. The definition and subdivision of the genus Actinomyces, with a preliminary account of Australian soil actinomycetes. Proc. Linn. Soc. N.S.W. 56:345-370

19. Marmur, J., and P. Doty. 1962. Determination of base composition of deoxyribonucleic acid from its thermal denaturation temperature. J. Mol. Biol. 5:109-118.

20. McClung, N. M. 1974. Nocardiaceae Castellani and Chalmers, p. 726-746. In R. E. Buchanan and N. E. Gibbons (ed.), Bergey's manual of determinative bacteriology, 8th ed. The Williams \& Wilkins Co., Baltimore.

21. Minnikin, D. E., M. Goodfellow, and M. D. Collins. 1978. Lipid composition in the classification and identification of coryneform and related taxa, p. 85-160. In I. J. Bousfield and A. G. Callely (ed.), Coryneform bacteria. Academic Press, Inc., London.

22. Mordarska, H., M. Mordarski, and D. Pietkiewicz 1973. Chemical analysis of hydrolysates and cell extracts of Nocardia pellegrino. Int. J. Syst. Bacteriol. 23:274277.

23. Mordarski, M., M. Goodfellow, K. Szyba, G. Pulverer, and A. Tkacz. 1977. Classification of the "rhodochrous" complex and allied taxa based upon deoxyribonucleic acid reassociation. Int. J. Syst. Bacteriol. 27:3137.

24. Mordarski, M. K. Szyba, G. Pulverer, and M. Goodfellow. 1976. Deoxyribonucleic acid reassociation in the classification of the "rhodochrous" complex and allied taxa. J. Gen. Microbiol. 94:235-245.

25. Okanishi, M., and K. F. Gregory. 1970. Methods for the determination of deoxyribonucleic acid homologies in Streptomyces. J. Bacteriol. 104:1086-1094.

26. Rowbotham, T. J., and T. Cross. 1977. Rhodococcus coprophilus sp. nov., an aerobic nocardioform actinomycete belonging to the "rhodochrous" complex. J. Gen. Microbiol. 100:123-138.

27. Rowbotham, T. J., and T. Cross. 1977. Ecology of Rhodococcus coprophilus and associated actinomycetes in freshwater and agricultural habitats. J. Gen. Microbiol. 100:231-240.

28. Runyon, E. H., L. G. Wayne, and G. P. Kubica. 1974. Mycobacterium Lehmann and Neumann, p. 681-701. In R. E. Buchanan and N. E. Gibbons (ed.), Bergey's manual of determinative bacteriology, 8 th ed. The Williams \& Wilkins Co., Baltimore.

29. Skerman, V. B. D., V. McGowan, and P. H. A. Sneath (ed.). 1980. Approved lists of bacterial names. Int. J. Syst. Bacteriol. 30:224-420.

30. Sneath, P. H. A. 1976. An evaluation of numerical taxonomic techniques in the taxonomy of Nocardia and allied taxa, p. 74-101. In M. Goodfellow, G. H. Brownell, and J. A. Serrano (ed.), The biology of the nocardiae. Academic Press, Inc., London.

31. Staley, T. E., and R. R. Colwell. 1973. Application of molecular genetics and numerical taxonomy to the classification of bacteria. Annu. Rev. Ecol. Syst. 4:273-300.

32. Tsukamura, M. 1971. Proposal of a new genus, Gordona, for slightly acid-fast organisms occurring in sputa of patients with pulmonary disease and in soil. J. Gen. Microbiol. 68:15-26.

33. Tsukamura, M., S. Mizuno, S. Tsukamura, and J. Tsukamura. 1979. Comprehensive numerical classification of 369 strains of Mycobacterium, Rhodococcus, and Nocardia. Int. J. Syst. Bacteriol. 29:110-129.

34. Zopf, W. 1891. Uber Ausscheidung von Fettfarbstoffen (Lipochromen) seitens gewisser Spaltpilze. Ber. Dtsch. Bot. Ges. 9:22-28. 